University of Arkansas, Fayetteville

ScholarWorks@UARK

Education Reform Faculty and Graduate

Students Publications

$5-11-2018$

\title{
Will Democracy Endure Private School Choice? The Effect of the Milwaukee Parental Choice Program on Adult Voting Behavior
}

Corey DeAngelis

Cato Institute

Patrick Wolf

University of Arkansas, Fayetteville

Follow this and additional works at: https://scholarworks.uark.edu/edrepub

Part of the Educational Assessment, Evaluation, and Research Commons, Educational Methods Commons, and the Social Influence and Political Communication Commons

\section{Citation}

DeAngelis, C., \& Wolf, P. (2018). Will Democracy Endure Private School Choice? The Effect of the Milwaukee Parental Choice Program on Adult Voting Behavior. Education Reform Faculty and Graduate Students Publications. Retrieved from https://scholarworks.uark.edu/edrepub/62

This Article is brought to you for free and open access by the Education Reform at ScholarWorks@UARK. It has been accepted for inclusion in Education Reform Faculty and Graduate Students Publications by an authorized administrator of ScholarWorks@UARK. For more information, please contact scholar@uark.edu. 


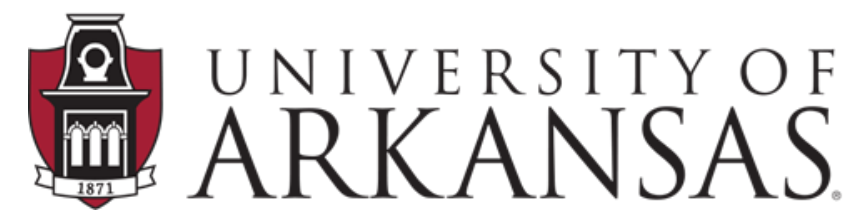

College of Education \& Health Professions Education Reform

\title{
WORKING PAPER SERIES
}

\section{Will Democracy Endure Private School Choice? The Effect of the Milwaukee Parental Choice Program on Adult Voting Behavior}

\author{
Corey A. DeAngelis, Ph.D. \\ Patrick J. Wolf, Ph.D.
}

May 11, 2018

EDRE Working Paper 2018-03

The University of Arkansas, Department of Education Reform (EDRE) working paper series is intended to widely disseminate and make easily accessible the results of EDRE faculty and students' latest findings. The Working Papers in this series have not undergone peer review or been edited by the University of Arkansas. The working papers are widely available, to encourage discussion and input from the research community before publication in a formal, peer reviewed journal. Unless otherwise indicated, working papers can be cited without permission of the author so long as the source is clearly referred to as an EDRE working paper. 


\title{
Will Democracy Endure Private School Choice? The Effect of the Milwaukee Parental Choice Program on Adult Voting Behavior
}

\author{
Corey A. DeAngelis, Ph.D. \\ Center for Educational Freedom, \\ Cato Institute \\ CDeAngelis@cato.org \\ Patrick J. Wolf, Ph.D. \\ Department of Education Reform, \\ University of Arkansas \\ pwolf@uark.edu
}

May 11, 2018

\section{Acknowledgements}

The content of the report is solely the responsibility of the authors and does not necessarily represent the views of the University of Arkansas or the Cato Institute. Corresponding author is Corey A. DeAngelis, CDeAngelis@ cato.org. Declaration of interest: none. Funding: none. 


\begin{abstract}
We employ probit regression analysis to compare the adult voting activity of students who participated in the Milwaukee Parental Choice Program (MPCP) to their matched public school counterparts. We use a sophisticated matching algorithm to create a traditional public school student comparison group using data from the state-mandated evaluation of the MPCP. By the time the students are 19-26 years old, we do not find evidence that private school voucher students are more or less likely to vote in 2012 or 2016 than students educated in public schools. These results are robust to all models and are consistent for all subgroups.

Keywords: school choice; private schooling; democratic education; political participation; civic education; school vouchers
\end{abstract}

JEL Codes: I28, I20 


\section{Introduction}

President Donald Trump called for an expansion of private school choice through a $\$ 20$ billion increase in federally-funded ${ }^{1}$ access to private schooling for each of the 11 million children living in poverty in 2017. Shortly after Trump was elected President of the United States, he appointed a supporter of private school choice, Betsy DeVos, as the Secretary of Education. During the same period, public interest in the idea of "school choice" reached an all-time high. ${ }^{2}$

Growing interest in the possibility of change in the nation's education system comes with growing fears regarding what critics call the "privatization" of education. One of the most often cited fears, discussed since the inception of the common schooling movement in the United States, is that democratic society would not function properly without traditional public schools instilling children with a uniform set of civic values. The so-called father of traditional American public schooling, Horace Mann (1855), and others (Dewey 1916; Rush 1786), arguably helped convince the nation to expand government-run schooling in the $19^{\text {th }}$ century. Today, some education scholars follow the beliefs of Mann, arguing that common schools are necessary to teach children from diverse backgrounds how to become proper citizens in a democracy (Gutmann, 1999). Other individuals, such as the President of the American Federation of Teachers, Randi Weingarten, claim ${ }^{3}$ that private school choice programs "undermine our democracy." She, along with other school choice opponents, claim that self-interested schooling selections would segregate ${ }^{4}$ society by income and race while failing to teach citizenship skills.

\footnotetext{
${ }^{1}$ Trump Budget Proposal Would Boost School Choice. U.S. News. https://www.usnews.com/news/nationalnews/articles/2017-03-16/trump-budget-proposal-would-boost-school-choice

${ }^{2}$ School Choice. Google Trends. https://trends.google.com/trends/explore?date=all\&q=school\%20choice

${ }^{3}$ School vouchers don't just undermine public schools, they undermine our democracy. Los Angeles Times. http://www.latimes.com/opinion/op-ed/la-oe-edelman-weingarten-school-vouchers-20170531-story.html ${ }^{4}$ AFT's Randi Weingarten blasts school-choice reforms as 'polite cousins of segregation.' The Washington Times. http://www.washingtontimes.com/news/2017/jul/21/Randi-Weingarten-blasts-school-choice-segregation/
} 
Likewise, people selecting their own schools may not choose institutions that specialize in shaping skills that accrue large benefits to third parties. In other words, self-interested customers of schooling may under-consume citizenship skills that have large positive externalities (Coase 1937; Pigou 1932). One citizen skill is to serve the rest of society by voting. An individual's vote is not likely to change their own lives substantially, so they are not likely to gain much of a private benefit through high-quality civic education. In addition, individuals know that their single vote has around a zero percent chance of determining the outcome of an election, while it is costly for people to acquire the information necessary to make an educated and responsible voting decision (Somin 2016). Indeed, if voting activity is purely explained by weighing private costs and benefits, it would be considered irrational for most people to go to the voting booth on Election Day (Caplan 2011).

That people show up to vote at all is evidence that individuals consider the impacts their decision to participate democratically has on the rest of society. But how much do individual decisions take into account these types of positive externalities? Of course, if individual decisions do not consider all positive externalities associated with civic education, they may not perfectly choose schools that maximize democratic participation.

In this study, we examine whether the private school choice program in Milwaukee alters voting behavior in the two most recent presidential elections. Since private schools have a financial incentive to shape character skills, and a previous study finds that the Milwaukee voucher program increases self-reports of planning to vote, we expect that actual voting activity will be higher for people that participated in the program than for those that attended traditional public schools, a hypothesis that runs contrary to prevailing democratic theory. 


\section{Theory}

Critics of private school choice programs have claimed that such a policy could negatively influence the foundations of a democratic society. Some education scholars argue that public schooling is required to inculcate a set of uniform citizenship skills that are necessary for a stable democratic society (Gutmann 1999; Apple \& Beane 1995). That way, common schools could teach a diverse set of children to get along with one another and to respect authority figures (Mann, 1855). It is argued that without a uniform set of values taught through public schooling, a democratic society will not function properly (Saltman 2000; Molnar 2013). After all, if private schools do not focus on shaping a population that is obedient to the state, students may be more likely to break the law when they grow up. Further, if children are not forced to get along with others in common schools, they may grow up to be less tolerant of groups with whom they do not agree.

Alternatively, private school choice programs could promote civic values such as voter participation through increased educational quality, an improved match between educator and student (DeAngelis \& Holmes Erickson 2018), and a higher likelihood of engaging in political discussions at school (DeAngelis 2017). Within the current system, traditional public schools hold a near monopoly on public resources. The monopoly power - exercised by the residentiallyassigned public schools - results in weak incentives to produce high-quality educational products at efficient costs (Hoxby 2007; Chubb \& Moe 1988). Indeed, public officials have an incentive to maximize budgets (Niskanen 1971). If a public official spends less than the budgeted amount, they will be financially harmed the following year by receiving less funding. On the other hand, if the official spends as much as possible, he or she will be rewarded the following year in two 
ways: (1) increased bargaining power for the need for more funding, and (2) the ability to gloat to constituents about all of the public resources they received.

Additionally, the public finance monopoly results in a scenario where private schools must attempt to compete with a free good. Because of this severe power imbalance in the education sector, traditional public schools do not face substantial financial costs for lowperformance. Since civic skills are included in the quality of an educational experience, a power imbalance, such as the one that exists in the education system today, can result in a dysfunctional society. On the other hand, if the collection of individuals within a society values civic skills, they can seek out schools that inculcate these values within a system that allows for families to select their educational product (Friedman \& Friedman 1990).

Moreover, the power imbalance in the education sector teaches children that their individual efforts will not likely impact the overall process. For example, if a family does not like what is going on within a traditional public school, they can use the democratic process to voice their opinions. They could express their concerns through the voting booth and even parent-teacher groups (Kahlenberg \& Janey 2016). However, if these types of democratic actions are largely unsuccessful in the K-12 educational experience, children may grow up to be less optimistic about the democratic system. As a result of learned helplessness, students may be less likely to engage in political activities as adults. ${ }^{5}$

Lastly, private schools may have a stronger incentive to foster discussions about controversial subjects such as politics. If children are more likely to debate sensitive subjects in their K-12 experience, they will be more likely to care about politics as adults. If they find that they disagree with others on important political topics in the classroom, and they care about

\footnotetext{
${ }^{5}$ Learned helplessness. Encyclopedia Britannica. https://www.britannica.com/topic/learned-helplessness
} 
public policy, they will have a robust incentive to go out and vote when they become adults. In addition, students and educators in private schools may be more open about discussing topics that would appear controversial in the public sphere. Since selection into and out of private schools is voluntary, and based on interests, students may feel more encouraged to discuss alternative viewpoints. On the other hand, students in a public setting may be more likely to fear insulting or offending teachers or other groups of students, so the controversial discussion may not happen at all (Berkman \& Plutzer 2010). Moreover, traditional public schools are largely incentivized by standardized test scores, so their teachers would be completely rational if they did not focus too much on sensitive subjects such as politics. After all, it can be quite stressful focusing on provocative political topics, especially when the difficult discussions do not necessarily translate into the standardized math or reading test scores that are the basis for public school accountability.

\section{The Milwaukee Parental Choice Program}

The Milwaukee Parental Choice Program (MPCP) is the longest-standing private school voucher program in the United States. The MPCP began in 1990 as a voucher program highlytargeted to disadvantaged families based on household income. At first, the MPCP was limited to 1.5 percent of Milwaukee Public Schools (MPS) enrollment, or about 500 students, and only seven non-religious private schools were allowed to participate (Witte 2000). In 1996, the program started to raise its enrollment cap until it was eventually eliminated in 2012 . The MPCP grew steadily and, by the 2014-15 school year, enrolled about a quarter of all K-12 students in the city.

In the baseline study year of 2006 , the voucher was worth up to $\$ 6,501$ per year, or about 40 percent less than the average per pupil expenditure in Milwaukee public schools (Costrell 
2009). To qualify for a voucher, applicants had to live in the city of Milwaukee, be entering grades K-12, and have a family income at or below 175 percent of the poverty level, an amount slightly below the ceiling to qualify for the federal lunch program.

Starting in 2017, students coming from families at or below 300 percent of the poverty line $-\$ 73,800$ for a family of four - were eligible for the program. Over 28,000 students and 121 school participated in the program in 2017, and 75 percent of Milwaukee families were eligible for the program based on income. ${ }^{6}$ The maximum voucher value was $\$ 7,969$ for grades $9-12$ and $\$ 7,323$ for grades $\mathrm{K}-8$, or a little over half of what is available for children in traditional public schools. Schools participating in the program must admit eligible students at random, administer state standardized tests, allow students to opt out of religious activities, and employ teachers who have a teaching license or a bachelor's degree.

\section{Literature Review}

The evidence on the impacts of private school choice programs on student achievement is extensive. While the exact results depend on the specific program, the overall evidence indicates that private school choice programs have small positive impacts on student test scores. Shakeel, Anderson, and Wolf's (2016) meta-analysis and systematic review of 19 experimental studies of voucher programs across the globe finds small positive impacts on student achievement overall. In particular, they find the largest effects for reading scores, publicly-funded programs, and programs located outside of the United States.

Out of the 17 existing experimental studies on the impacts of U.S. voucher programs on student achievement, only two find negative effects (Abdulkadiroglu et al. 2018; Dynarski et al. 2017). Eleven of the 17 studies find positive impacts for some or all students (e.g. Cowen 2008;

\footnotetext{
${ }^{6}$ Milwaukee Parental Choice Program. EdChoice. https://www.edchoice.org/school-choice/programs/wisconsinmilwaukee-parental-choice-program/
} 
Greene 2001; Wolf et al. 2013), while four find no effects (Bitler et al. 2013; Bettinger \& Slonim 2006; Krueger \& Zhu 2004; Mills \& Wolf 2017). In addition, voucher programs tend to produce test score effects that improve with time (Shakeel, Anderson, \& Wolf 2016). For example, while the voucher programs in Louisiana and Indiana negatively affect student test scores in initial years, choice students catch up to their peers in public schools after three years (Mills \& Wolf 2017; Waddington \& Berends 2017). Both of the experimental studies on the voucher program in Milwaukee find positive impacts (Greene, Peterson, \& Du 1999; Rouse 1998), with the recent evaluation of the MPCP showing that the program improves student standardized math scores by 11 points and reading scores by 6 points (Greene, Peterson, \& Du 1999).

Although the evidence on test scores is quite robust, it appears not to align closely with the less extensive evidence on arguably more important long-term outcomes such as graduation rates, criminal activity, and income (Greene 2016). In fact, Hitt, McShane, and Wolf (2018) report that "there is a weak relationship between impacts on test scores and later attainment outcomes" for school choice programs in the United States. The state-mandated evaluations of the D.C. Opportunity Scholarship Program (OSP) and the Milwaukee Parental Choice Program find little or no student achievement gains alongside large increases in high school graduation (Cowen et al. 2013; Wolf et al. 2013) and crime reduction (DeAngelis \& Wolf 2016). Additionally, the evaluation of the New York School Choice Scholarships Foundation (SCSF) finds modest student test score improvements alongside more substantial college enrollment gains (Chingos \& Peterson 2015). This observed trend is not restricted to private school choice programs. At least six charter school studies have shown a nontrivial disconnect between short and long term outcomes (Abdulkadiroğlu et al. 2016; Angrist et al. 2016; Booker et al. 2014; Dobbie \& Fryer 2016; Clark et al. 2015; Unterman et al. 2016). 
If short-run standardized test scores are not strong proxies for the outcomes that society actually cares about, it is important that researchers shift attention towards long-term outcomes. Overall, the evidence indicates that private school choice programs increase high school graduation (Cowen et al. 2013; Wolf et al. 2013), save the state and local school districts money (Costrell 2009; Scafidi 2012; Trivitt \& DeAngelis 2016) and increase performance in public schools as a result of competitive effects (Egalite 2013; Egalite \& Wolf 2016).

The evidence on the impacts of private school choice programs on democratic society overall is quite scarce, but the abundance of the rigorous empirical studies indicates that private school choice improves civic outcomes. There are two reviews of the empirical evidence on how school choice impacts democratic outcomes such as citizenship skills, civic engagement, tolerance of others, and criminal activity. The most recent review (DeAngelis 2017) of the eleven quasi-experimental and experimental studies on the effects of private school choice on civic outcomes finds that effects are null to positive for tolerance (Campbell 2002; Fleming, Mitchell, \& McNally 2014; Howell \& Peterson 2006; Mills et al. 2016; Peterson \& Campbell 2001; Wolf, Peterson, \& West 2001), null to positive for civic engagement (Bettinger \& Slonim 2006; Carlson, Chingos, \& Campbell 2017; Fleming 2014; Fleming, Mitchell, \& McNally 2014), and positive for crime reduction (DeAngelis \& Wolf 2016). Patrick Wolf's (2007) meta-analysis and review of 21 quantitative studies on the subject, in which he used a less stringent methodology screen than DeAngelis (2017), also finds that school choice largely improves civic outcomes. Twenty-two out of 23 findings from experimental or other statistically rigorous studies indicate that choice schools perform at par with, or better than, traditional public schools at shaping democratic outcomes. The same result emerges from less rigorous empirical studies as well; only 
2 out of 36 findings indicate that traditional public schools have an advantage at improving civic skills.

The only experiment examining the relationship between voucher participation and actual voting activity, set in New York City, does not find any impacts overall or for subgroups (Carlson, Chingos, \& Campbell 2017). However, the previous study of the MPCP's impact on voter activity, using data from the state-mandated evaluation of the program, finds moderately large positive effects. Specifically, the MPCP students have an 11-percentage point - or 20 percent - higher likelihood of reporting that they would certainly vote in future elections than their matched public school peers (Fleming, Mitchell, \& McNally 2014). If students are much more likely to report that they will vote in future elections while they are in the program, we should expect them to have higher voter participation as adults. Our current study is the first to rigorously assess the impacts of the Milwaukee voucher program on actual voting activity using student-level data.

If actual voting activity does not reveal that voucher students actually engage in more political activity, as found in New York City, two possible explanations exist: (1) the previous study captures the voucher program's ability to shape the skill of understanding social expectations but does not further motivate students to fulfill those expectations, or (2) the program actually shapes the skills necessary to boost civic participation but the effects fade out by the time the children become adults.

\section{Data and Matching}

We use matched student-level data from the state-mandated evaluation of the MPCP. While schools participating in the program are required to admit students via lottery when they are oversubscribed, school leaders in Milwaukee typically recruit voucher students until they 
have filled all of their seats. As a result, most school admissions do not require a lottery in Milwaukee. Consequently, we are highly restricted in our ability to experimentally study this voucher program (Cowen et al. 2013).

Instead, we used a sophisticated matching procedure in an attempt to replicate an experimental setting. Specifically, we generated comparable groups by using an algorithm that matched voucher (MPCP) students with Milwaukee Public School (MPS) students based on grade, neighborhood, race, gender, English Language Learner (ELL) status, and math and reading test scores (Witte et al. 2008). Researchers took the entire census of 801 MPCP students who were in $9^{\text {th }}$ grade in the fall of 2006 , along with a randomly-selected representative sample of 290 MPCP students in $8^{\text {th }}$ grade during the same year, to organize a total MPCP student sample of 1091. Each MPCP student was matched to an MPS student in their exact grade and census tract, which define neighborhoods in Milwaukee. We further restricted matches to MPS students that were in the same 5 percent bandwidth of 2006 math and reading test scores. Finally, the specific MPS student that served as the match for each MPCP student was selected based on the nearest-neighbor propensity score calculated by student race, gender, ELL status, and test score. All but two students were successfully matched, so the final program sample consisted of 1089 students exposed to the voucher program in 2006 and a matched group of 1089 similar comparison students in MPS in 2006, for a total sample of 2,178.

The match on geographic location was essential since an appropriately common concern with any program evaluation is the fact that participants choose to receive treatment for unobservable reasons. Importantly, families that live in the same neighborhoods tend to share similar unmeasured background characteristics such as motivation level and morality that may have otherwise biased our examination of the MPCP (Ahlbrandt 2013). Previous research shows 
that non-experimental matching designs which consider geographic location can come close to replicating gold-standard experimental results (Bifulco 2012).

After students were matched, their parents were surveyed by telephone to gather important family background information such as family income, mother's and father's education, and whether both parents lived in the home. The telephone survey was administered by researchers at Westat's survey call center in two waves - an initial wave in NovemberDecember of 2006 and a follow-up wave limited to initial non-respondents in NovemberDecember of 2007. The survey instrument, described in detail in Witte et al. (2008), drew upon questions asked of participants in previous school voucher evaluations in Milwaukee; New York City; Dayton, Ohio; and Washington, DC; with some refinements by the research team. A total of 69 percent of parents in both the MPCP and MPS samples eventually responded - a very high response rate for a telephone survey. The response rate for MPCP parents was 73 percent while the rate for MPS parents was 66 percent. In the analysis below, we use response weights to correct for any baseline differences. For our more complete model estimations we use this subsample of 1506 students whose parents were survey respondents so that we can control for family background characteristics that might otherwise bias our estimation of the voucher program effect on voting activity.

For our three dependent variables of interest, we searched publicly available voting records for each student from the state of Wisconsin. Specifically, we were able to find these records online at the My Vote Wisconsin ${ }^{7}$ website using the student's name and date of birth. Over a three-day time period in December 2016, researchers who were blind to the treatment status of each student recorded whether or not the student was registered to vote, and whether or

\footnotetext{
${ }^{7}$ My Vote Wisconsin. State of Wisconsin Elections Commission. https://myvote.wi.gov/en-us/MyVoterInfo
} 
not they voted in the 2012 or 2016 elections. By 2012, the matched students were between 19 and 22 years of age, and by 2016, they were between 23 and 26 years of age.

Table 1 below shows the observable differences between MPCP and MPS students after the baseline match. Overall, students differed on only one characteristic included in the 2006 match. MPCP students averaged around a tenth of a standard deviation higher baseline reading score than their matched MPS students. Additionally, MPCP students were more likely to have a parent that frequently attended church and 4 percentage points more likely to have parents that completed college, indicating that MPCP students may have been a more-advantaged group. However, MPCP students were 13-percentage points less likely to be in the highest income group and 7-percentage points less likely to have a parent that graduated from high school, indicating that MPCP students may have been a less-advantaged group.

Consequently, the direction of the selection bias, if it exists, is unclear. The MPCP students could have more-motivated parents, but they could also be those in most-need of an enhanced education. Nonetheless, we control for all of these characteristics in each of our analytical models. Table 1 also indicates no differences on the three measures of voter participation in 2012 or 2016. Table 2 includes descriptive statistics of each variable used in our models. 
Table 1: Statistics on Model Covariates

\begin{tabular}{|c|c|c|c|}
\hline & MPCP in 2006 & MPS in 2006 & $\mathrm{~N}$ \\
\hline Female & 0.5676 & 0.5298 & 2178 \\
\hline Black & 0.6983 & 0.6966 & 2178 \\
\hline Hispanic & 0.1923 & 0.1760 & 2178 \\
\hline Math in 2006 & -0.0310 & 0.0396 & 2178 \\
\hline Reading in 2006 & $0.1257 * *$ & 0.0179 & 2178 \\
\hline Income $>50 \mathrm{k}$ & 0.0473 & $0.1740 * * *$ & 1401 \\
\hline $35 \mathrm{k}<$ Income $<50 \mathrm{k}$ & 0.1446 & 0.1392 & 1401 \\
\hline $25 \mathrm{k}<$ Income $<35 \mathrm{k}$ & $0.2135 * *$ & 0.1498 & 1401 \\
\hline Parent HS Grad & 0.2566 & $0.3273 * *$ & 1506 \\
\hline Parent Some College & 0.3502 & 0.3119 & 1506 \\
\hline Parent Completed College & $0.1643^{*}$ & 0.1245 & 1506 \\
\hline Both Parents in $\mathrm{HH}$ & 0.3485 & 0.3296 & 1502 \\
\hline Parent Frequent Churchgoer & $0.6399 * * *$ & 0.5070 & 1500 \\
\hline Registered in 2016 & 0.5236 & 0.5591 & 2170 \\
\hline Voted in 2012 & 0.4782 & 0.4977 & 2170 \\
\hline Voted in 2016 & 0.2410 & 0.2356 & 2170 \\
\hline
\end{tabular}

Notes: $* \mathrm{p}<0.05, * * \mathrm{p}<0.01, * * * \mathrm{p}<0.001$; All figures are the proportions of observations with the described characteristic except test scores, which are expressed in z-score units.

Table 2: Descriptive Statistics

\begin{tabular}{l|ccccc}
\hline Variable & $\mathrm{N}$ & Mean & Std. Dev. & Min & Max \\
\hline MPCP in 2006 & 2178 & .50 & .50 & 0 & 1 \\
$9^{\text {th }}$ Grade & 2178 & .74 & .44 & 0 & 1 \\
Black & 2178 & .70 & .46 & 0 & 1 \\
Hispanic & 2178 & .18 & .39 & 0 & 1 \\
Female & 2178 & .55 & .50 & 0 & 1 \\
Income>50 & 1401 & .11 & .31 & 0 & 1 \\
35<Income<50 & 1401 & .14 & .35 & 0 & 1 \\
25<Income<35 & 1401 & .18 & .39 & 0 & 1 \\
Parent HS Grad & 1506 & .29 & .45 & 0 & 1 \\
Parent Some College & 1506 & .33 & .47 & 0 & 1 \\
Parent Completed College & 1506 & .15 & .35 & 0 & 1 \\
Math Z Score & 2178 & .00 & .87 & -3 & 3 \\
Read Z Score & 2178 & .07 & .90 & -3 & 2.5 \\
Both Parents in HH & 1502 & .34 & .47 & 0 & 1 \\
Parent Frequent Churchgoer & 1500 & .58 & .49 & 0 & 1 \\
\hline Registered in 2016 & 2170 & .54 & .50 & 0 & 1 \\
Voted in 2012 & 2170 & .49 & .50 & 0 & 1 \\
Voted in 2016 & 2170 & .24 & .43 & 0 & 1 \\
\hline
\end{tabular}

Notes: All figures are the proportions of observations with the described characteristic except test scores, which are expressed in z-score units. 


\section{Methods}

Since our three dependent variables of interest are binary, we employ a probit regression model of the form:

$$
\text { VoterActivity }_{i}=\beta_{0}+\beta_{1} \text { MPCP06 }_{i}+\beta_{2} X_{i}+\beta_{3} Z_{i}+\beta_{4} \text { test }_{2006}+\varepsilon_{i}
$$

Our dependent variable of interest, VoterActivity, takes on the value of 1 if the student engaged in the voting activity in time period $t$ and 0 otherwise. We perform a separate probit regression for each of our three outcome variables: whether the student was registered to vote in 2016, whether the student voted in 2012, and whether the student voted in 2016.

Our binary explanatory variable of interest, $M P C P 06$, takes on the value of 1 if a given student, $i$, was exposed to the voucher program at baseline and 0 otherwise. Students are classified as "exposed" to the program if they were enrolled in a private school using a voucher in the fall of 2006, regardless of where they attended school after that point. Fall of 2006 was the point at which the MPCP students were matched to MPS students. Using that point as a measure of "exposure" to the treatment of private schooling through a voucher renders our analysis similar to an "intent-to-treat" analysis in the context of an experiment, where subsequent student sorting is controlled for by being ignored. The outcomes for 2006 MPCP students who later switch to MPS or drop out of school altogether are averaged in with the outcomes for 2006 MPCP students who stay in the voucher program through high school. Similarly, the outcomes for 2006 MPS students who subsequently enroll in the MPCP or drop out of school entirely are averaged in with the outcomes for 2006 MPS students who stay in the public school district throughout high school. Essentially, we control for possible student self-selection bias through 2006 through the matching protocol and then control for possible student self-selection bias after 2006 through using exposure to MPCP in 2006 as our variable of interest. 
Although we use a rigorous matching procedure that may be able to replicate experimental results (Bifulco 2012), we present models with parent and student-level controls. We include vector $\mathrm{X}$ of student-level controls and vector $\mathrm{Z}$ of parent-level controls. These include student grade, race, gender, churchgoing activity, parent income, parent education, and whether or not both parents lived in the household.

We use robust standard errors in all probit models due to the heteroskedastic nature of models with binary dependent variables. We cluster robust standard errors by census tract since students within the same geographic region are similar on unobservable characteristics. We also employ linear probability models as robustness checks for our results.

\section{Results}

Table 3 below presents our overall results for our two main models. Our results based on the entire matched sample with student-level controls can be found in columns one through three while the results based on the subsample with all student and parent-level controls can be found in columns three through six.

Overall, neither model indicates that voucher program participation is associated with more or less voting activity in 2012 or 2016 . Our model that only uses student-level controls indicates that MPCP students were 4.6-percentage points less likely to be registered to vote in 2016. Since the incidence rate of voter registration in 2016 was 50 percent, voucher students were 9.2-percent less likely to be registered to vote in 2016 . However, this effect attenuates to zero in our model which includes all control variables. All statistical significance levels and estimates presented are robust to linear probability models with standard errors clustered at the census tract level. 
Control variables mostly behave as expected across models and outcomes. However, in our sample, black students were much more politically active than white students in 2012 . In particular, black students were about 12-percentage points more likely to vote in 2012 than white students, perhaps because of the historically unique incumbent candidate for president. This result is not surprising, as United States voting data ${ }^{8}$ shows that the historically-high black turnout of 67 percent in 2012 had already dropped to 36 percent by 2014 . This is equivalent to a 24 percent higher likelihood of blacks in our sample voting in 2012 than whites. This large voter participation difference between races disappears to zero for the 2016 presidential election.

Students of Hispanic descent were less likely to vote than white students, and females were more likely to vote than males in both elections. Remarkably, females were 12-percentage points more likely to vote than males in 2016, perhaps because citizens expected a female to be elected president for the first time in United States history. Relative to the incidence rate of only 24 percent in 2016, this is an exceptionally large 50 percent higher likelihood of females voting in 2016 than males.

Students with higher baseline reading scores and students with more-educated parents were more likely to vote. Students with more-educated parents were more likely to vote in 2012; however, this effect diminishes to zero by 2016 , perhaps because individuals are less likely to be influenced by their parents by the time they reach 23 to 26 years of age. Alternatively, this result could be explained by the fact that Donald Trump garnered strong support from less-educated segments of the population. ${ }^{9}$ Unexpectedly, having a two-parent household did not relate to any voting outcome, conceivably because the variable is collinear with income and education.

\footnotetext{
${ }^{8}$ Voter Turnout Demographics. United States Elections Project. http://www.electproject.org/home/voterturnout/demographics

${ }^{9}$ Behind Trump's victory: Divisions by race, gender, education. Pew Research Center.

http://www.pewresearch.org/fact-tank/2016/11/09/behind-trumps-victory-divisions-by-race-gender-education/
} 
Table 3: Effect of MPCP on Voter Activity

\begin{tabular}{|c|c|c|c|c|c|c|}
\hline & $\begin{array}{l}\text { (1) } \\
\text { Registered } \\
\text { in } 2016\end{array}$ & $\begin{array}{l}(2) \\
\text { Voted in } \\
2012\end{array}$ & $\begin{array}{l}(3) \\
\text { Voted in } \\
2016\end{array}$ & $\begin{array}{l}\text { (4) } \\
\text { Registered } \\
\text { in } 2016\end{array}$ & $\begin{array}{l}(5) \\
\text { Voted in } \\
2012\end{array}$ & $\begin{array}{l}(6) \\
\text { Voted in } \\
2016\end{array}$ \\
\hline МРCP 2006 & $\begin{array}{l}-0.046 * \\
(0.026)\end{array}$ & $\begin{array}{c}-0.028 \\
(0.205)\end{array}$ & $\begin{array}{l}0.001 \\
(0.972)\end{array}$ & $\begin{array}{l}-0.034 \\
(0.208)\end{array}$ & $\begin{array}{c}-0.021 \\
(0.484)\end{array}$ & $\begin{array}{l}0.005 \\
(0.842)\end{array}$ \\
\hline $9^{\text {th }}$ Grade & $\begin{array}{l}-0.004 \\
(0.852)\end{array}$ & $\begin{array}{l}0.004 \\
(0.874)\end{array}$ & $\begin{array}{l}-0.035 \\
(0.105)\end{array}$ & $\begin{array}{l}-0.037 \\
(0.173)\end{array}$ & $\begin{array}{l}-0.032 \\
(0.263)\end{array}$ & $\begin{array}{l}-0.047 \\
(0.068)\end{array}$ \\
\hline Black & $\begin{array}{l}0.093 * * \\
(0.003)\end{array}$ & $\begin{array}{l}0.128 * * * \\
(0.000)\end{array}$ & $\begin{array}{l}-0.038 \\
(0.180)\end{array}$ & $\begin{array}{l}0.079 \\
(0.052)\end{array}$ & $\begin{array}{l}0.102 * \\
(0.017)\end{array}$ & $\begin{array}{l}-0.044 \\
(0.257)\end{array}$ \\
\hline Hispanic & $\begin{array}{l}-0.105^{* *} \\
(0.005)\end{array}$ & $\begin{array}{l}-0.102 * * \\
(0.010)\end{array}$ & $\begin{array}{l}-0.076 * \\
(0.039)\end{array}$ & $\begin{array}{l}-0.123 * \\
(0.021)\end{array}$ & $\begin{array}{l}-0.118 * \\
(0.023)\end{array}$ & $\begin{array}{l}-0.062 \\
(0.238)\end{array}$ \\
\hline Female & $\begin{array}{l}0.167 * * * \\
(0.000)\end{array}$ & $\begin{array}{l}0.173 * * * \\
(0.000)\end{array}$ & $\begin{array}{l}0.123 * * * \\
(0.000)\end{array}$ & $\begin{array}{l}0.169 * * * \\
(0.000)\end{array}$ & $\begin{array}{l}0.183^{* * * *} \\
(0.000)\end{array}$ & $\begin{array}{l}0.117 * * * \\
(0.000)\end{array}$ \\
\hline Math & $\begin{array}{l}0.003 \\
(0.814)\end{array}$ & $\begin{array}{l}0.011 \\
(0.508)\end{array}$ & $\begin{array}{l}0.004 \\
(0.780)\end{array}$ & $\begin{array}{l}0.025 \\
(0.153)\end{array}$ & $\begin{array}{l}0.019 \\
(0.308)\end{array}$ & $\begin{array}{l}0.010 \\
(0.527)\end{array}$ \\
\hline Reading & $\begin{array}{l}0.049 * * \\
(0.001)\end{array}$ & $\begin{array}{l}0.038 * * \\
(0.008)\end{array}$ & $\begin{array}{l}0.031 * \\
(0.017)\end{array}$ & $\begin{array}{l}0.044 * \\
(0.018)\end{array}$ & $\begin{array}{l}0.039 * \\
(0.046)\end{array}$ & $\begin{array}{l}0.034 * \\
(0.041)\end{array}$ \\
\hline High Income & & & & $\begin{array}{l}0.040 \\
(0.425)\end{array}$ & $\begin{array}{l}0.050 \\
(0.313)\end{array}$ & $\begin{array}{l}0.051 \\
(0.301)\end{array}$ \\
\hline Mid Income & & & & $\begin{array}{l}-0.056 \\
(0.203)\end{array}$ & $\begin{array}{l}-0.079 \\
(0.078)\end{array}$ & $\begin{array}{l}-0.010 \\
(0.809)\end{array}$ \\
\hline Low Income & & & & $\begin{array}{l}-0.069 \\
(0.088)\end{array}$ & $\begin{array}{l}-0.078 \\
(0.050)\end{array}$ & $\begin{array}{l}-0.064 \\
(0.089)\end{array}$ \\
\hline HS Grad & & & & $\begin{array}{l}0.156 * * * \\
(0.000)\end{array}$ & $\begin{array}{l}0.134 * * * \\
(0.000)\end{array}$ & $\begin{array}{l}0.052 \\
(0.148)\end{array}$ \\
\hline Some College & & & & $\begin{array}{l}0.108 * * \\
(0.004)\end{array}$ & $\begin{array}{l}0.124 * * * \\
(0.001)\end{array}$ & $\begin{array}{l}0.029 \\
(0.398)\end{array}$ \\
\hline College & & & & $\begin{array}{l}0.105^{*} \\
(0.026)\end{array}$ & $\begin{array}{l}0.118 * \\
(0.014)\end{array}$ & $\begin{array}{l}0.053 \\
(0.301)\end{array}$ \\
\hline Both Parents & & & & $\begin{array}{l}0.007 \\
(0.821)\end{array}$ & $\begin{array}{l}0.013 \\
(0.690)\end{array}$ & $\begin{array}{l}-0.037 \\
(0.236)\end{array}$ \\
\hline
\end{tabular}




\begin{tabular}{|c|c|c|c|c|c|c|}
\hline Church & & & & $\begin{array}{l}0.011 \\
(0.657)\end{array}$ & $\begin{array}{l}-0.020 \\
(0.419)\end{array}$ & $\begin{array}{l}0.008 \\
(0.742)\end{array}$ \\
\hline Pseudo $\mathrm{R}^{2}$ & 0.0463 & 0.0506 & 0.0287 & 0.0716 & 0.0756 & 0.0361 \\
\hline $\mathrm{N}$ & 2170 & 2170 & 2170 & 1378 & 1378 & 1378 \\
\hline
\end{tabular}

Notes: P-values in parentheses. Robust standard errors clustered by census tract. Estimates are average marginal effects. Models $1-3$ use student-level controls. Models $4-6$ use student and parent-level controls. All significance levels and coefficients are robust to linear probability models. ${ }^{*} \mathrm{p}<0.05, * * \mathrm{p}<0.01,{ }^{* * *} \mathrm{p}<0.001$

Table 4 below shows the results for various subgroups. These results largely mirror those for the overall sample. Subgroup analyses by race, gender, and baseline test scores do not detect any heterogeneous effects of the program on voting in either year. However, the model without parental controls finds that voucher students with below average math and reading baseline test scores were less likely to be registered to vote in 2016. Specifically, voucher students with below-average math or reading test scores were about 6.8-percentage points less likely to be registered to vote in 2016. 
Table 4: Heterogeneous Effects of MPCP on Voter Activity

\begin{tabular}{|c|c|c|c|c|c|c|}
\hline & $\begin{array}{l}(1) \\
\text { Registered } \\
\text { in } 2016\end{array}$ & $\begin{array}{l}(2) \\
\text { Voted in } \\
2012\end{array}$ & $\begin{array}{l}(3) \\
\text { Voted in } \\
2016\end{array}$ & $\begin{array}{l}(4) \\
\text { Registered } \\
\text { in } 2016\end{array}$ & $\begin{array}{l}(5) \\
\text { Voted in } \\
2012\end{array}$ & $\begin{array}{l}\text { (6) } \\
\text { Voted in } \\
2016\end{array}$ \\
\hline White & $\begin{array}{l}-0.061 \\
(0.127)\end{array}$ & $\begin{array}{l}-0.067 \\
(0.082)\end{array}$ & $\begin{array}{l}-0.022 \\
(0.499)\end{array}$ & $\begin{array}{l}-0.049 \\
(0.312)\end{array}$ & $\begin{array}{l}-0.042 \\
(0.420)\end{array}$ & $\begin{array}{l}-0.006 \\
(0.884)\end{array}$ \\
\hline Black & $\begin{array}{l}-0.038 \\
(0.628)\end{array}$ & $\begin{array}{l}-0.012 \\
(0.260)\end{array}$ & $\begin{array}{l}0.010 \\
(0.405)\end{array}$ & $\begin{array}{l}-0.027 \\
(0.707)\end{array}$ & $\begin{array}{l}-0.013 \\
(0.639)\end{array}$ & $\begin{array}{l}0.010 \\
(0.761)\end{array}$ \\
\hline Female & $\begin{array}{l}-0.053 \\
(0.711)\end{array}$ & $\begin{array}{l}-0.031 \\
(0.867)\end{array}$ & $\begin{array}{l}0.004 \\
(0.763)\end{array}$ & $\begin{array}{l}-0.06 \\
(0.239)\end{array}$ & $\begin{array}{l}-0.051 \\
(0.160)\end{array}$ & $\begin{array}{l}0.002 \\
(0.836)\end{array}$ \\
\hline Male & $\begin{array}{l}-0.037 \\
(0.219)\end{array}$ & $\begin{array}{l}-0.025 \\
(0.430)\end{array}$ & $\begin{array}{l}-0.006 \\
(0.845)\end{array}$ & $\begin{array}{l}-0.003 \\
(0.947)\end{array}$ & $\begin{array}{l}0.018 \\
(0.680)\end{array}$ & $\begin{array}{l}0.011 \\
(0.780)\end{array}$ \\
\hline Low Reading & $\begin{array}{l}-0.065^{*} \\
(0.011)\end{array}$ & $\begin{array}{l}-0.047 \\
(0.064)\end{array}$ & $\begin{array}{l}0.014 \\
(0.554)\end{array}$ & $\begin{array}{l}-0.041 \\
(0.217)\end{array}$ & $\begin{array}{l}-0.021 \\
(0.534)\end{array}$ & $\begin{array}{l}0.030 \\
(0.294)\end{array}$ \\
\hline Low Math & $\begin{array}{l}-0.071^{* *} \\
(0.002)\end{array}$ & $\begin{array}{l}-0.039 \\
(0.109)\end{array}$ & $\begin{array}{l}0.006 \\
(0.775)\end{array}$ & $\begin{array}{l}-0.048 \\
(0.092)\end{array}$ & $\begin{array}{l}-0.024 \\
(0.427)\end{array}$ & $\begin{array}{l}0.012 \\
(0.649)\end{array}$ \\
\hline Dropout Parent & & & & $\begin{array}{l}-0.047 \\
(0.784)\end{array}$ & $\begin{array}{l}-0.001 \\
(0.682)\end{array}$ & $\begin{array}{l}-0.022 \\
(0.542)\end{array}$ \\
\hline Student Controls & $\mathrm{X}$ & $\mathrm{X}$ & $\mathrm{X}$ & $\mathrm{X}$ & $X$ & $X$ \\
\hline Parent Controls & & & & $\mathrm{X}$ & $\mathrm{X}$ & $\mathrm{X}$ \\
\hline
\end{tabular}

Notes: P-values in parentheses. Robust standard errors clustered by census tract. Estimates are average marginal effects. Results in columns $1-3$ include student controls, while columns $4-6$ also include parental controls. * $\mathrm{p}<0.05, * * \mathrm{p}<0.01, * * * \mathrm{p}<0.001$

\section{Discussion and Policy Implications}

While some scholars may suggest that these results conflict with the conclusions made by Fleming, Mitchell, and McNally (2014), we are not particularly surprised. There are two highly plausible explanations for the seemingly-contradictory results between the two studies. The other study simply asks these children if they believe that they are going to vote in the future. 
Consequently, this survey question likely measures something other than political participation. In fact, it is much more likely that this question measures another arguably essential skill for social order: knowing what is implicitly and explicitly expected from the rest of society. It appears that the MPCP has a positive influence on that particular civic skill, but no effect on actual voting activity in 2012 or 2016. Alternatively, it may be that the positive impact on voting activity captured by Fleming, Mitchell, \& McNally (2014) simply fades out by the time the students reach 19 to 26 years of age.

Our study largely mirrors the experimental results reported by Carlson, Chingos, \& Campbell (2017) for the New York School Choice Scholarships Foundation Program: no impacts on voter activity overall or for any subgroups. Likewise, our study does not find evidence to suggest that access to private schooling through a voucher program diminishes the ability of a democratic society to function properly. Indeed, prior research finds that access to the MPCP results in an improved society through less criminal activity (DeAngelis \& Wolf 2016), an understanding of the expectations of society (Fleming, Mitchell, \& McNally 2016), more racial integration (Forster 2006; Fuller \& Greiveldinger 2002; Fuller \& Mitchell 2000), higher test scores (Greene, Peterson, \& Du 1999), higher graduation rates (Cowen et al. 2013), and higher levels of college enrollment (Wolf, Witte, \& Kisida 2018), without any social costs associated with diminished voting behavior.

Indeed, one could argue a finding that access to private schooling significantly effects voter participation, in either direction, would be cause for concern. If access to religious schools caused an increase in voting activity, there would be much anxiety about how those students ended up voting. If it caused a decrease in voting activity, concerns about a weakening of civic values would be strengthened. Since access to private schooling through the MPCP only appears 
to benefit individuals through an enhanced education and the rest of society through improved social order, and has no discernable effect on civic participation, decision-makers should increase access to the program. 


\section{References}

Abdulkadiroğlu, A., Angrist, J. D., Hull, P. D., \& Pathak, P. A. (2016). Charters without lotteries: Testing takeovers in New Orleans and Boston. American Economic Review, 106(7), 1878-1920.

Abdulkadiroğlu, A., Pathak, P. A., \& Walters, C. R. (2018). Free to choose: can school choice reduce student achievement? American Economic Journal: Applied Economics, 10(1), 175-206.

Ahlbrandt, R. (2013). Neighborhoods, people, and community. New York, NY: Plenum Press.

Angrist, J. D., Cohodes, S. R., Dynarski, S. M., Pathak, P. A., \& Walters, C. R. (2016). Stand and deliver: Effects of Boston's charter high schools on college preparation, entry, and choice. Journal of Labor Economics, 34(2), 275-318.

Apple, M. W., \& Beane, J. A. (1995). Democratic schools. Association for Supervision and Curriculum Development, 1250 North Pitt Street, Alexandria, VA.

Berkman, M., \& Plutzer, E. (2010). Evolution, creationism, and the battle to control America's classrooms. Cambridge, UK: Cambridge University Press.

Bettinger, E., \& Slonim, R. (2006). Using experimental economics to measure the effects of a natural educational experiment on altruism. Journal of Public Economics, 90(8), 16251648.

Bitler, M. P., Domina, T., Penner, E. K., \& Hoynes, H. W. (2013). Distributional effects of a school voucher program: Evidence from New York City. NBER Working Paper w19271.

Booker, K., Gill, B., Sass, T., \& Zimmer, R. (2014). Charter High Schools’ Effects On Educational Attainment and Earnings. Princeton, NJ: Mathematica Policy Research. Retrieved from https://www.mathematica-mpr.com//media/publications/pdfs/education/charter_high_schools_ib.pdf.

Campbell, D. E. (2002). The civic side of school reform: how do school vouchers affect civic education? Education Next, 1(3), 55.

Caplan, B. (2011). The myth of the rational voter: Why democracies choose bad policies. Princeton, NJ: Princeton University Press.

Chubb, J. E., \& Moe, T. M. (1988). Politics, markets, and the organization of schools. American Political Science Review, 82(4), 1065-1087.

Clark, M. A., Gleason, P. M., Tuttle, C. C., \& Silverberg, M. K. (2015). Do charter schools improve student achievement? Educational Evaluation and Policy Analysis, 37(4), 419436. 
Coase, R. H. (1937). The nature of the firm. Economica, 4(16), 386-405.

Cowen, J. M. (2008). School choice as a latent variable: Estimating the "complier average causal effect" of vouchers in Charlotte. Policy Studies Journal, 36(2), 301-315.

Cowen, J. M., Fleming, D. J., Witte, J. F., Wolf, P. J., \& Kisida, B. (2013). School vouchers and student attainment: Evidence from a state-mandated study of Milwaukee's Parental Choice Program. Policy Studies Journal, 41(1), 147-168.

Carlson, D., Chingos, M. M., \& Campbell, D. E. (2017). The effect of private school vouchers on political participation: Experimental evidence from New York City. Journal of Research on Educational Effectiveness, 10(3), 545-569.

Chingos, M. M., \& Peterson, P. E. (2015). Experimentally estimated impacts of school vouchers on college enrollment and degree attainment. Journal of Public Economics, 122(February), 1-12.

Costrell, R. M. (2009). Who gains, who loses? Education Next, 9(1).

DeAngelis, C. A. (2017). Do self-interested schooling selections improve society? A review of the evidence. Journal of School Choice, 11(4), 546-558.

DeAngelis, C. A., \& Erickson, H. H. (2018). What leads to successful school choice programs? A review of the theories and evidence. Cato Journal, 38(1), 247-263.

DeAngelis, C., \& Wolf, P. J. (2016). The school choice voucher: A 'get out of jail' card? EDRE Working Paper 2016-03. Available at SSRN: https://ssrn.com/abstract=2743541.

Dewey J. (1916). Democracy and education. New York: The Macmillan Company.

Dobbie, W. S., \& Fryer Jr, R. G. (2016). Charter schools and labor market outcomes. NBER Working Paper w 22502. Retrieved from http://www.nber.org/papers/w22502.

Dynarski, M., Rui, N., Webber, A., \& Gutmann, B. (2017). Evaluation of the DC Opportunity Scholarship Program: Impacts after one year. NCEE 2017-4022. National Center for Education Evaluation and Regional Assistance. Retrieved from https://ies.ed.gov/ncee/pubs/20174022/.

Egalite, A. J. (2013). Measuring competitive effects from school voucher programs: A systematic review. Journal of School Choice, 7(4), 443-464.

Egalite, A.J., \& Wolf, P.J. (2016, Fall). A review of the empirical research on private school choice. Peabody Journal of Education, 91(4), 441-454.Fleming, D. J. (2014). Learning from schools: School choice, political learning, and policy feedback. Policy Studies Journal, 42(1), 55-78. 
Fleming, D. J., Mitchell, W., \& McNally, M. (2014). Can markets make citizens? School vouchers, political tolerance, and civic engagement. Journal of School Choice, 8(2), 213236.

Forster, G. (2006). Segregation levels in Milwaukee Public Schools and the Milwaukee voucher program. Milton \& Rose D. Friedman Foundation. Retrieved from https://eric.ed.gov/?id=ED508491.

Fuller, H., \& Greiveldinger, D. (2002). The impact of school choice on racial integration in Milwaukee private schools. Howard Fuller. Retrieved from howard.fuller@marquette.edu.

Fuller, H., \& Mitchell, G. (2000). The impact of school choice on integration in Milwaukee (Report MU-CAS-CEI-2000-02). Milwaukee, WI: Marquette University.

Greene, J. P. (2001). Vouchers in Charlotte. Education Next, 1(2).

Greene (2016). Evidence for the disconnect between changing test scores and changing later life outcomes. Education Next. Retrieved from http://educationnext.org/evidence-for-thedisconnect-between-changing-test-scores-and-changing-later-life-outcomes/

Greene, J. P., Peterson, P. E., \& Du, J. (1999). Effectiveness of school choice: The Milwaukee experiment. Education and Urban Society, 31(2), 190-213.

Gutmann, A. (1999). Democratic education. Princeton, NJ: Princeton University Press.

Hitt, C., McShane, M. Q., \& Wolf, P. J. (2018). Do impacts on test scores even matter? Lessons from long-run outcomes in school choice research. American Enterprise Institute. Retrieved from http://www.aei.org/publication/do-impacts-on-test-scores-even-matterlessons-from-long-run-outcomes-in-school-choice-research/.

Howell, W. G., \& Peterson, P. E. (2006). The education gap: Vouchers and urban schools. Washington, DC: Brookings Institution Press.

Hoxby, C. M. (Ed.). (2007). The economics of school choice. Chicago, IL: University of Chicago Press.

Kahlenberg, R. D., \& Janey, C. (2016). Putting democracy back into public education. The Century Foundation. Retrieved from https://tcf.org/content/report/putting-democracyback-public-education/.

Krueger, A. B., \& Zhu, P. (2004). Another look at the New York City school voucher experiment. American Behavioral Scientist, 47(5), 658-698.

Mann, H. (1855). Lectures on education. Boston, MA: WB Fowle and N. Capen. 
Mills, J. N., \& Wolf, P. J. (2017). The effects of the Louisiana Scholarship Program on student achievement after three years. Louisiana Scholarship Program Evaluation Report \#7. School Choice Demonstration Project, University of Arkansas.

Mills, J. N., Cheng, A., Hitt, C., Wolf, P. J., \& Greene, J. P. (2016). Measures of student noncognitive skills and political tolerance after two years of the Louisiana Scholarship Program. Louisiana Scholarship Program Evaluation Report \#2. School Choice Demonstration Project, University of Arkansas.

Molnar, A. (2013). School commercialism: From democratic ideal to market commodity. New York, NY: Routledge.

Niskanen, W. A. (1971). Bureaucracy and representative government. New Brunswick, NJ: Transaction Publishers.

Peterson, P. E., \& Campbell, D. E. (2001). An evaluation of the Children's Scholarship Fund. KSG Working Paper No. RWP02-020. Retrieved from https://papers.ssrn.com/sol3/papers.cfm?abstract_id=430540.

Pigou, A. C. (1932). The economics of welfare, 1920. London, UK: McMillan\&Co.

Rouse, C. E. (1998). Private school vouchers and student achievement: An evaluation of the Milwaukee Parental Choice Program. Quarterly Journal of Economics, 113(2), 553-602.

Rush, B. (1786). Thoughts upon the mode of education proper in a republic. In Rudolph, F. (1968) (Ed.) Essays on education in the early republic. Cambridge, MA.

Saltman, K. J. (2000). Collateral damage: Corporatizing public schools--a threat to democracy. Lanham, MD: Rowman \& Littlefield.

Scafidi, B. (2012). The fiscal effects of school choice programs on public school districts. National Research. Friedman Foundation for Educational Choice.

Shakeel, M., Anderson, K. P., \& Wolf, P. J. (2016). The participant effects of private school vouchers across the globe: A meta-analytic and systematic review. EDRE Working Paper No. 2016-07. Available at SSRN: https://ssrn.com/abstract=2777633.

Somin, I. (2016). Democracy and political ignorance: Why smaller government is smarter. Redwood City, CA: Stanford University Press.

Trivitt, J. R. \& DeAngelis (2016). The fiscal effect of eliminating the Louisiana Scholarship Program on state education expenditures. EDRE Working Paper No. 2016-06. Available at SSRN: https://ssrn.com/abstract=2768956.

Unterman, R., Bloom, D., Byndloss, D., \& Terwelp, E. (2016). Going away to school: An evaluation of SEED DC. MDRC. Retrieved from https://ssrn.com/abstract=2821816. 
Waddington, R. J., \& Berends, M. (2017). Impact of the Indiana Choice Scholarship Program: Achievement effects for students in upper elementary and middle school. Future Ed Working Paper, Georgetown University. Retrieved from https://www.future-ed.org/wpcontent/uploads/2017/06/Waddington-Berends-Indiana-Voucher-Impacts-06.24.17E.pdf.

Witte, J. F. (2000). The Market Approach to Education: An Analysis of America's First Voucher Program. Princeton, NJ: Princeton University Press.

Wolf, P. J., Kisida, B., Gutmann, B., Puma, M., Eissa, N., \& Rizzo, L. (2013). School vouchers and student outcomes: Experimental evidence from Washington, DC. Journal of Policy Analysis and Management, 32(2), 246-270.

Wolf, P. J., Peterson, P. E., \& West, M. R. (2001). Results of a school voucher experiment: The case of Washington, DC after two years. KSG Working Paper No. RWP02-022. Retrieved from https://ssrn.com/abstract=313822.

Wolf, P. J., Witte, J. F., \& Kisida, B. (2018). Do voucher students attain higher levels of education? Extended evidence from the Milwaukee Parental Choice Program. Urban Institute Research Report. Retrieved from https://www.urban.org/research/publication/do-voucher-students-attain-higher-levelseducation.

Wolf, P. J. (2007). Civics exam. Education Next, 7(3). 